\title{
Subtotal Pancreatectomy for Chronic Pancreatitis
}

\author{
Frederic Eckhauser, M.D., ${ }^{1}$ Robert Cowles, M.D., ${ }^{3}$ Lisa Colletti, M.D. ${ }^{2}$ \\ ${ }^{1}$ Department of Surgery, Johns Hopkins Bayview Medical Center, 4940 Eastern Avenue, Baltimore, Maryland 21224, USA \\ ${ }^{2}$ Department of Surgery, University of Michigan Medical Center, 1500 E. Medical Center Drive, Ann Arbor 48109, Michigan, USA \\ ${ }^{3}$ Department of Surgery, Children's Hospital of New York-Presbyterian, 3959 Broadway, Rm 201N, New York, New York 10032, USA
}

Published Online: October 13, 2003

\begin{abstract}
Chronic pancreatitis results when pancreatic structure or function is irreversibly damaged by repeated or ongoing inflammation, regardless of the underlying etiology. Most patients present with medically intractable pain and radiological evidence of diffuse gland involvement. Surgical therapy is directed mainly toward palliation of symptoms, and cure is unusual except when the inflammatory process is limited to a specific segment of the pancreas. Surgical strategy should be individualized on the basis of alterations in pancreatic morphology and duct anatomy. In properly selected patients, duct drainage procedures effectively relieve pain and preserve pancreatic function with low perioperative morbidity and mortality. Extensive distal pancreatectomy is effective in relieving pain, but it can be technically challenging and in general should be limited to patients with small-duct disease because of severe metabolic consequences. Intraportal islet cell autotransplantation or segmental pancreatic autotransplantation may ameliorate the long-term effects of insulin-dependent diabetes, but it will have limited applicability until methods for optimizing and purifying islets are developed and the optimal route and site of islet cell implantation have been identified.
\end{abstract}

Chronic pancreatitis is prevalent throughout the world, but the etiologies and clinical course vary in different regions. Although the pathophysiology remains unclear, the clinical manifestations of pain and malabsorption occur with predictable regularity. The inflammatory component of the disease is incurable, and conventional treatment strategies are directed toward palliation of symptoms and management of complications. Medical treatment is generally effective, and fewer than one-third of patients require surgery during the course of their disease [1].

Pain is, without question, the most common and troublesome presenting symptom in patients with chronic pancreatitis. The pathogenesis is complex, multifactorial, and poorly understood. The two most widely accepted and well-studied mechanisms of chronic pain include "pancreatic duct-parenchymal hypertension" and "perineural inflammation." Several authors have demonstrated elevated pancreatic tissue pressure in patients with painful pancreatitis and noted good correlation between relief of pain and normalization of tissue pressure after duct decompression [2, 3]. The concept of pancreatitis-associated neuritis was suggested by

Correspondence to: F. Eckhauser, M.D.
Bockman et al., and is based on histologic evidence of disproportionate round cell infiltration of pancreatic nerve plexuses [4]. Presumably, cytotoxic enzymes released by eosinophils and other round cells damage the normal perineural barrier and permit the influx of inflammatory mediators and pancreatic enzymes, causing pain.

\section{Indications for Surgery}

The course of chronic pancreatitis is erratic, but in severe cases it can progress to intractable pain, inanition, and chemical dependency with narcotic habituation, loss of gainful employment, and the need for repeated hospitalizations. Intractable pain continues to be the main indication for surgical intervention. Although elimination of the underlying cause (e.g., alcohol) may alter the clinical course of the disease, morphological changes such as duct obstruction, calculus formation, and fibrosis ultimately perpetuate parenchyma damage. The restrictive effects of ongoing inflammation and fibrosis result in a situation that is analogous to "compartment syndromes" observed in other areas of the body.

The purported goal of medical, endoscopic, and surgical approaches is reduction of ductal and parenchymal hypertension. Surgical intervention is limited to managing complications of the disease, but timing of surgery and selection of a specific surgical approach that is both safe and effective remain controversial. No single surgical procedure is uniformly appropriate for all patients with painful pancreatitis. Because there is no clear-cut association between the pain of chronic pancreatitis and the results of imaging and/or function studies, therapeutic recommendations should continue to be based primarily on clinical assessment. Operative strategy should be individualized on the basis of alterations in pancreatic morphology and duct anatomy. The severity and chronicity of pain, as well as the degree of narcotic analgesic and other chemical dependencies, should be assessed. Nutritional and immunologic parameters should be measured preoperatively, and provision of enteral or parenteral supplements should be considered in any patient with extreme weight loss and/or malnutrition.

Diabetes and steatorrhea are the ultimate manifestations of pan- 
creatic endocrine and exocrine insufficiency, respectively. The combination of these findings with radiological evidence of glandular calcification in a patient with painful pancreatitis generally connotes irreversible disease that is unlikely to respond to continued medical management. With continued refinement of diagnostic imaging studies, the importance of pancreatic function studies has diminished. Although somewhat cumbersome and technologydependent, the secretin-cholecystokinin stimulation test with duodenal intubation remains the "gold standard" for diagnosing chronic pancreatitis [5]. Additional studies are available, but they tend to be expensive and are relatively insensitive in early stages of chronic pancreatitis.

The success of surgical intervention ultimately is dependent on tailoring a specific procedure to each individual patient's needs. This in turn is determined by the patient's pancreatic morphology and ductal anatomy. Plain radiographs of the abdomen help to establish the diagnosis of chronic pancreatitis, but they are rarely helpful in planning operative intervention. Computed tomography (CT) and endoscopic retrograde cholangiopancreatography (ERCP) remain the mainstays of diagnosis. In particular, ERCP is useful in identifying abnormalities that might alter the surgical approach, and it provides potential access for nonoperative treatment of strictures and stones. Despite initial enthusiasm for endoscopic treatment of strictures and stones, critical analysis suggests that it is currently experimental and should be limited to centers participating in comparative, prospective trials [6].

Computed tomography may be useful in demonstrating unsuspected complications (e.g., pseudocyst or splenic vein thrombosis) that might alter surgical strategy. Visceral angiography is rarely indicated because sophisticated helical or spiral CT scans can reliably demonstrate relevant peripancreatic vascular anatomy. However, angiography may be useful in selected patients with suspected or proven pancreatitis-associated visceral pseudoaneurysms in whom operative intervention is contemplated.

Distal pancreatectomy is indicated for chronic pancreatitis patients with intractable pain in whom most of the disease is limited to the distal pancreas and for patients with "small-duct" disease in whom a duct drainage procedure is not likely to be successful. Duct drainage is clearly preferred in patients with "large-duct" pancreatitis characterized by marked dilatation $(>7-8 \mathrm{~mm})$ of the main pancreatic duct, because it can be accomplished with low morbidity and mortality, is technically less challenging than formal pancreatic resection, and preserves islet cell mass, thereby reducing the likelihood of insulin-dependent diabetes. Reoperation rates approaching $20 \%$ after initial duct decompression indicate inadequate drainage or disease progression. Several technical maneuvers are critical to insure the success of duct decompression. First, a long segment $(8-10 \mathrm{~cm})$ of duct must be unroofed. Second, intraductal concretions obstructing side branches should be carefully removed to eliminate foci of smoldering pancreatitis. Third, probe patency of the proximal pancreatic duct should be demonstrated. Fourth, the intestinal and pancreatic duct mucosa should be carefully apposed to insure long-term anastomotic patency.

In addition to relieving pain in up to $80 \%$ of patients, drainage operations for large-duct pancreatitis may also help to preserve pancreatic endocrine and exocrine function. Several authors have observed improvements in diabetes with stabilization of insulin requirements as well as preservation of exocrine function after a modified Puestow procedure [7, 8]. These data have led to liberalization of the indications for surgical duct decompression, espe- cially in patients with preserved pancreatic function and only mild to moderate pain. The reported operative risks for duct decompression and pancreatic resection are generally comparable. However, extensive distal pancreatic resection can be a formidable undertaking and is associated with a high incidence of metabolic complications related to pancreatic endocrine and exocrine insufficiency. Some authors question the efficacy of distal resection for pain management, even with radiological evidence of a stricture or occlusion of the pancreatic duct [9]. However, most surgeons believe that limited distal pancreatectomy is indicated in selected patients with chronic inflammation or a pseudocyst confined to the tail of the gland. Other indications for distal resection include suspected malignancy and left-sided, or sinistral, portal hypertension resulting from splenic vein thrombosis.

Preservation of the spleen during distal pancreatectomy is desirable because of its immunological role in opsonization of encapsulated bacteria, but it is not always technically feasible because of inflammation and fibrosis that obscure normal anatomical planes in the splenic hilum. The procedure can either begin distally with mobilization and elevation of the spleen and pancreatic tail or proximally with division of the neck of the pancreas. Warshaw described a technique in which the main splenic artery and vein are deliberately divided, maintaining splenic viability through the short gastric vessels [10]. Although attempted spleen preservation in patients with chronic pancreatitis undergoing distal resection is worthwhile, a word of caution is warranted. Because of perturbations in anatomy, successful splenic preservation can be achieved in less than one-third of these patients. Furthermore, division of the main splenic vessels can infrequently lead to left-sided portal hypertension and variceal bleeding that might later require splenectomy.

The results of limited distal pancreatectomy are difficult to interpret because the technique(s) of resection and the indications for resection are highly variable. Sawyer and Frey showed that strict patient selection based on radiological evidence of disease limited to the body and tail of the pancreas, as well as clinical inspection of the gland at the time of operation, was critical for determining outcome [11]. In their series of 17 patients with small-duct disease, 9 of 10 properly selected patients had a good result, whereas none of the 7 patients with more diffuse disease had a good result. Of these 7 patients, 5 required reoperation within 12 months of their initial surgery. In a more recent study, Rattner et al. achieved fair to good results in 14 of 20 patients ( $70 \%$ ) with small-duct disease, and they observed that patients with unequivocal evidence of disease limited to the tail of the pancreas were most likely to have a good result [9].

Extensive or near-total distal pancreatectomy has generally been reserved for patients with small-duct disease or recurrent pain after a duct drainage procedure or limited pancreatic resection. This procedure removes $80 \%$ to $95 \%$ of the distal pancreas, leaving in situ a small rim of gland along the C-loop of the duodenum. This operative technique is well illustrated in Cameron's Atlas of Surgery [12]. Briefly, the procedure consists of mobilizing the tail, body, and neck of the pancreas away from the portal and superior mesenteric veins, and exposing the uncinate process by dissecting it from beneath the superior mesenteric artery and vein. Having fully mobilized the uncinate process from the retroperitoneum, a metal dilator or semi-rigid catheter is placed within the common bile duct to ascertain its position and course through the substance of the pancreatic head. Once the course of the common bile duct has been established, the pancreas is divided, leaving a $0.5-$ to $1.0-\mathrm{cm}$ rim of 
tissue to protect the bile duct from injury. Preservation of both pancreaticoduodenal arteries is preferable, but one can be ligated without compromising the viability of the duodenum. Inadvertent ligation of both pancreaticoduodenal arteries necessitates duodenectomy. Once the pancreas has been divided, the pancreatic duct is identified and ligated. In all cases the pancreatic remnant should be drained externally.

The results of near-total distal pancreatectomy (NTP) for painful chronic pancreatitis should lead us to question the efficacy of this procedure. Keith et al. demonstrated complete freedom from pain on long-term follow-up in 16 of 32 patients (50\%) who underwent $80 \%$ distal resection with only one postoperative death [13]. Fifty percent of patients developed new-onset diabetes, but management was uncomplicated in those patients who abstained from alcohol. In a similar study, Eckhauser et al. evaluated 87 patients who underwent NTP for management of intractable pain resulting from chronic pancreatitis [14]. Significant improvement or complete pain relief was achieved in $75 \%$ of patients, with a perioperative mortality rate of $3.4 \%$. Fourteen percent of patients remained narcotic dependent. Of the 44 patients who developed insulindependent diabetes after operation, 36 (82\%) were new-onset diabetics who had no evidence of glucose intolerance prior to operation. The cumulative survival rate at 10 years was $60 \%$, and contrary to what we might have predicted, was comparable in patients with alcoholic and non-alcoholic etiologies.

Intraportal islet cell autotransplantation and segmental pancreatic autotransplantation may ameliorate the metabolic complications of extensive pancreatic resection, but the efficacy of these strategies remains unproved. Of the 71 cases of intraportal islet cell autotransplantation reported by Sutherland and Najarian, 33 patients $(46 \%)$ remained insulin-independent for an extended time after surgery [15]. The main obstacles to successful islet cell autotransplantation include our inability to preoperatively assess adequacy of islet cell mass, suboptimal techniques for isolating and purifying islets, and lack of understanding regarding the optimal site and route of islet cell implantation.

Segmental pancreatic autotransplantation is another potential treatment option to avoid insulin dependence after extensive pancreatic resection, but clinical data are sparse. Fewer than 25 cases have been reported, with a $20 \%$ operative failure rate and a $14 \%$ insulin-independence rate in patients followed for a minimum of 2 years [16]. The major complications of this approach are related to controlling pancreatic exocrine secretions, ensuring early graft survival, and optimizing late graft function. Until better solutions are developed to reduce the incidence of post-transplant fistulas and to halt whatever changes are responsible for progression deterioration of graft function over time, these procedures will have limited applicability in the management of these difficult chronic pancreatitis patients.

\section{Summary and Conclusions}

The treatment of chronic pancreatitis must be highly individualized, because no uniform approach is applicable to all patients. Therapeutic decisions should be based on objective information pertaining to duct anatomy and pancreatic function and should be tempered by awareness of the metabolic perturbations that accompany extensive pancreatic resection. Patients with large-duct disease who fail endoscopic therapy should be considered initially for duct drainage rather than pancreatic resection to relieve pain and possibly delay irreversible impairment of pancreatic function.
Small-duct disease presents a particularly difficult problem. Limited distal resection may be warranted in selected patients with focal disease involving the body and tail of the pancreas. However, most of these patients will require more extensive resection. The metabolic consequences of near-total distal pancreatectomy are significant and may be prohibitive in patients with underlying alcoholism who are unable or unwilling to remain abstinent following operation. The endocrine sequelae of NTP can be partially offset by segmental pancreatic autotransplantation or intraportal islet cell transplantation, but availability of these techniques is generally limited to referral centers with established expertise. Interpretation of data from clinical trials comparing different operative approaches is difficult because classification criteria have not been standardized. Improved efforts to classify the severity of chronic pancreatitis based on evaluation of changes in pancreatic morphology and function will become increasingly important in the comparison of the results obtained with different therapies.

Résumé. On parle de pancréatite chronique lorsque la structure ou la fonction pancréatique sont lésées de façon irréversible par une inflammation répétée ou continue, quelle qu'en soit l'étiologie. La plupart des patients ont une douleur rebelle et des signes radiologiques intéressant toute la glande. La thérapeutique chirurgicale a comme but de pallier les symptômes: la cure est peu fréquente sauf lorsque l'inflammation est limitée à une seule portion du pancréas. La stratégie chirurgicale doit être individualisée, basée sur les altérations de la morphologie pancréatique et sur l'anatomie canalaire. Chez des patients sélectionnés, les procédés de drainage permettent de bien soulager la douleur et de conserver une fonction pancréatique avec une morbidité et mortalité périopératoires acceptables. La pancréatectomie distale étendue, même si elle est efficace en ce qui concerne le soulagement de la douleur, peut être techniquement un défi et en général, devrait être indiquée uniquement aux patients dont les canaux ne sont pas dilatés en raison des conséquences métaboliques sévères. L'autotransplantation pancréatique segmentaire ou intra portale des îlots de pancréas peuvent améliorer les résultats à long terme en ce qui concerne le diabète insulinodépendant, mais pourrait avoir une applicabilité limitée jusqu'à ce que l'on développe des méthodes pour optimiser et purifier les îlots ainsi que d'identifier la route et le site idéal de l'implantation des îlots.

Resumen. A parte de la enfermedad subyacente, la pancreatitis crónica se origina como consecuencia de las lesiones irreversibles de la morfología o función del páncreas, secundarios a procesos inflamatorios reiterativos. La mayoría de los pacientes aquejan un dolor incoercible, resistente a todo tratamiento médico, observándose radiológicamente una afectación difusa de la glándula. El tratamiento quirúrgico tiene por objeto paliar la sintomatología ya que no existe cura posible, excepto en aquellos casos en los que el proceso inflamatorio se limite a un segmento específico de la glándula. La estrategia quirúrgica ha de individualizarse basándose en las alteraciones morfológicas del páncreas y de la anatomía del Wirsung y conductos colaterales. En pacientes bien seleccionados, las operaciones que permiten drenar el Wirsung son eficaces tanto para el tratamiento del dolor como para preservar la función pancreática, cursando con escasa morbi-mortalidad postoperatoria. La pancreatectomía distal ampliada, es eficaz para aliviar el dolor, pero puede ser dificultosa desde el punto de vista técnico; por lo general su indicación queda limitada a pacientes con Wirsung estrecho pues conlleva graves alteraciones metabólicas. El autotrasplante de islotes de celulas de Langerhans a través de la vena porta y de segmentos pancreáticos, mejoran a largo plazo la diabetes insulinodependiente; para que sean más efectivos se requiere optimizar la purificación de los islotes e identificar la vía y la ubicación idónea de los mismos.

\section{References}

1. Layer P, Yamamoto H, Kalthof L, et al. The different courses of early and late onset idiopathic and alcoholic chronic pancreatitis. Gastroenterology 1994;107:1481-1487 
2. Ebbehoj N, Borly L, Rasmussen SG, et al. Evaluation of pancreatic tissue fluid pressure and pain in chronic pancreatitis. A longitudinal study. Scand. J. Gastroenterol. 1990;25:462-466

3. Jalleh RP, Aslam M, Williamson RCN. Pancreatic tissue pressures and ductal pressures in chronic pancreatitis. Br. J. Surg. 1991;78:1235-1237

4. Bockman DE, Buchler M, Malfertheiner P, et al. Analysis of nerves in chronic pancreatitis. Gastroenterology 1988;94:1459-1469

5. Sidhu S, Tandon RK. Chronic pancreatitis: diagnosis and treatment. Postgrad. Med. J. 1996;72:327-333

6. Burdick JS, Hogan WJ. Chronic pancreatitis: selection of patients for endoscopic therapy. Endoscopy 1991;23:255-260

7. Nealon WH, Thompson JC. Progressive loss of pancreatic function in chronic pancreatitis is delayed by main pancreatic duct decompression. Ann. Surg. 1993;217:458-468

8. Sidu S, Tandon RK, Nundy S. Chronic calcific pancreatitis: a prospective study of response to surgical treatment. Indian J. Gastroenterol. 1994;13:J2

9. Rattner DW, del-Castillo F, Warshaw AL. Pitfalls of distal pancreatectomy for relief of pain in chronic pancreatitis. Am. J. Surg. 1996;171: $142-146$
10. Warshaw AL. Conservation of the spleen during distal pancreatectomy. Arch. Surg. 1988;123:550-553

11. Sawyer R, Frey CF. Is there still a role for distal pancreatectomy in surgery for chronic pancreatitis? Am. J. Surg. 1994;168:6-9

12. Cameron JL. $95 \%$ distal pancreatectomy for chronic pancreatitis. In Atlas of Surgery, Vol 1. Toronto, B.C. Decker, Inc., 1990;363-365

13. Keith RG, Saibil FG, Sheppard RH. Treatment of chronic alcoholic pancreatitis by pancreatic resection. Am. J. Surg. 1989;157:156-162

14. Eckhauser FE, Strodel WE, Knol JA, et al. Near-total pancreatectomy for chronic pancreatitis. Surgery 1984;96:599-606

15. Sutherland DER, Najarian JS. Pancreas and islet transplantation. In Brooks JR, editor, Surgery of the Pancreas Philadelphia, W.B. Saunders, 1983:434

16. Eckhauser FE, Turcotte JG. Current trends and new developments in the surgical management of chronic pancreatitis. In Zuidema GD, editor, Shackleford's Surgery of the Alimentary Tract Philadelphia, W.B. Saunders, 1991:37 